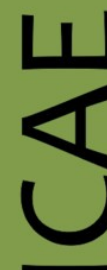

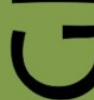

ex Instituto Archaeologico Universitatis de Rolando Eötvös nominatae

O

$\overrightarrow{0}$

山

$\leftarrow$

I

$\cup$

ه

$\leftarrow$

u

Ш

Z

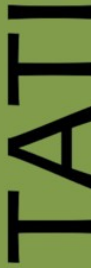

œ

ш

n

n

$\varnothing$
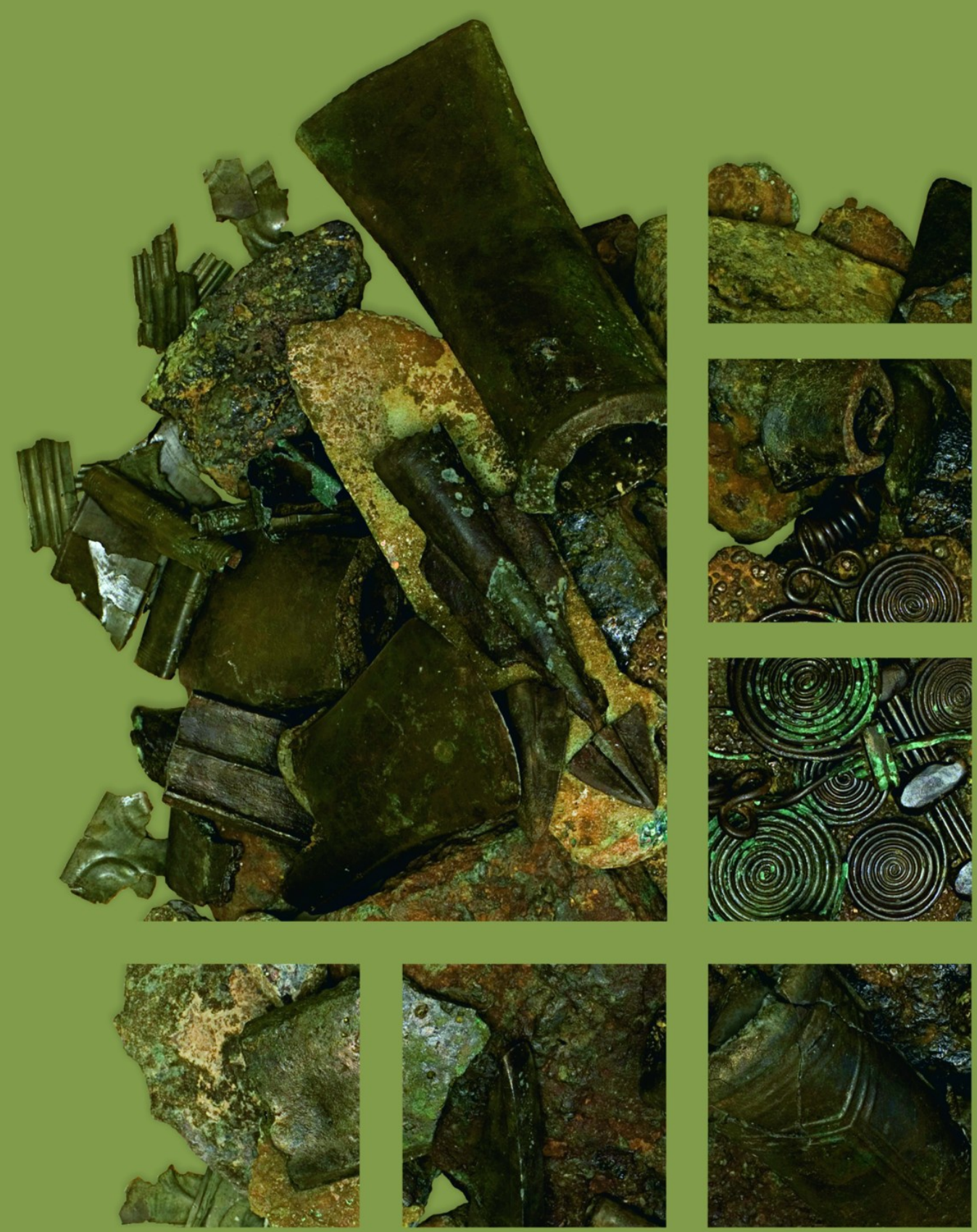


\section{Dissertationes Archaeologicae ex Instituto Archaeologico}

Universitatis de Rolando Eötvös nominatae Ser. 3. No. 2.

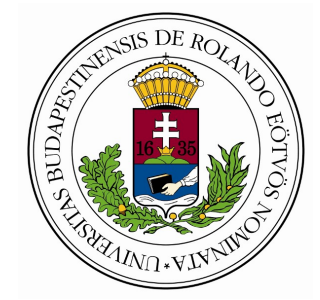

Budapest 2014 
Dissertationes Archaeologicae ex Instituto Archaeologico Universitatis de Rolando Eötvös nominatae

Ser. 3. No. 2.

Editor-in-chief:

DÁvid BARTus

Editorial board:

LÁsZló BARTOSIEWICZ

LÁSZLÓ BORHY

IsTVÁN FELD

GÁBOR KALLA

PÁL RACZKY

MiKLÓs SzABÓ

TIVADAR VIDA

Technical editors:

DÁvid BARTus

GÁBOR VÁCZI

ANDRÁs BÖDŐCS

DÁNIEL SZABÓ

Proofreading:

SZILVIA SzÖLLősI

Available online at http://dissarch.elte.hu Contact: dissarch@btk.elte.hu

$$
\begin{aligned}
& \text { PUBLIC } \\
& \text { KNOWLEDGE } \\
& \text { PROJECT }
\end{aligned}
$$

(c) Eötvös Loránd University, Institute of Archaeological Sciences

Budapest 2014 


\section{Contents}

\section{SElected PAPERS OF THE XI. Hungarian CONFERENCE on Classical Studies}

Ferenc BARNA

Venus mit Waffen. Die Darstellungen und die Rolle der Göttin in der Münzpropaganda

der Zeit der Soldatenkaiser (235-284 n. Chr.)

Dénes GABLER

A belsó vámok szerepe a rajnai és a dunai provinciák importált kerámiaspektrumában

Lajos MATHÉDESZ

Római bélyeges téglák a komáromi Duna Menti Múzeum gyújteményében

Katalin OtTOMÁNYI

Újabb római vicusok Aquincum territoriumán

Eszter SÜVEGH

Hellenistic grotesque terracotta figurines. Problems of iconographical interpretation

András SzABó

Some notes on the rings with sacred inscriptions from Pannonia

István VIDA

The coinage of Flavia Maxima Helena

\section{Articles}

Gábor TARBAY

Late Bronze Age depot from the foothills of the Pilis Mountains

Csilla SÁRó

Roman brooches from Paks-Gyapa - Rosti-puszta

András BöDőcs - Gábor KovÁcs - Krisztián ANDERKó

The impact of the roman agriculture on the territory of Savaria

Lajos JuHÁsz

Two new Roman bronzes with Suebian nodus from Brigetio

\section{FIELD REPORTS}

Zsolt MESTER - Norbert FARAGó - Attila KirÁLy

The first in situ Old Stone Age assemblage from the Rába Valley, Northwestern Hungary

Pál RACZky - Alexandra ANDERs - Norbert FARAgó - Gábor MÁRKus

Short report on the 2014 excavations at Polgár-Csőszhalom 
Preliminary Report on the first season of fieldwork in Berettyóúffalu-Szilhalom

Márton SzILÁgyi - András FüZESI - Attila VIRÁG - Mihály GASPARIK

A Palaeolithic mammoth bone deposit and a Late Copper Age Baden settlement and enclosure

Preliminary report on the rescue excavation at Szurdokpüspöki - Hosszú-dúlö II-III. (M21 site No. 6-7)

Kristóf FüLÖP - Gábor VÁcZI

Preliminary report on the excavation of a new Late Bronze Age cemetery

from fobbágyi (North Hungary)

Lőrinc TimÁr - Zoltán CzAJLik - András BöDőcs - Sándor PuszTA

Geophysical prospection on the Pâture du Couvent (Bibracte, France). The campaign of 2014

Dávid BARtus - László Borhy - Gabriella Delbó - Emese SzÁmadó

Short report on the excavations in the civil town of Brigetio (Szőny-Vásártér) in 2014

Dávid BARTus - László BorHy - Emese SzÁMADó

A new Roman bath in the canabae of Brigetio

Short report on the excavations at the site Szőny-Dunapart in 2014

Dávid BARTus - László Borhy - Zoltán CzAjlik - Balázs Holl -

Sándor PuszTA - László RuPNiK

Topographical research in the canabae of Brigetio in 2014

Zoltán CZAJLIK - Sándor BERECKI - László RUPNIK

Aerial Geoarchaeological Survey in the Valleys of the Mureș and Arieș Rivers (2009-2013)

Maxim MoRDovin

Short report on the excavations in 2014 of the Department of Hungarian Medieval

and Early Modern Archaeology (Eötvös Loránd University, Budapest)

Excavations at Castles Čabrad' and Drégely, and at the Pauline Friary at Sáska

\section{Thesis Abstracts}

Piroska Csengeri

Late groups of the Alföld Linear Pottery culture in north-eastern Hungary

New results of the research in Borsod-Abaúj-Zemplén County

Ádám Bíró

Weapons in the 10-11th century Carpathian Basin

Studies in weapon technology and methodology - rigid bow applications and southern import

swords in the archaeological material

Márta DARÓcZI-SzABó

Animal remains from the mid 12th-13th century (Árpád Period) village of Kána, Hungary

Károly BELÉNYESY

A 15th-16th century cannon foundry workshop in Buda

Craftsmen and technology of cannon moulding and the transformation of military technology

from the Renaissance to the Post Medieval Period 
István RINGER

Manorial and urban manufactories in the 17th century in Sárospatak

\section{BIBLIOGRAPHY}

László BORHY

565

Bibliography of the excavations in Brigetio (1992-2014) 


\title{
A 15th-16th century cannon foundry workshop in Buda Craftsmen and technology of cannon moulding and the transformation of military technology from the Renaissance to the Post Medieval Period
}

\author{
KÁROLy BELÉNYESY \\ belenyesy@gmail.com
}

\begin{abstract}
PhD thesis submitted in 2014 to the Archaeology Doctoral Programme, Doctoral School of History, Eötvös Loránd University, Budapest under the supervision of András Kubinyi and István Feld.
\end{abstract}

\section{Introduction}

The reconstruction and architectural rehabilitation of the Szent György Square was a very late but very important part of the post-war renovation (following the demolitions of World War II in 1944-45) of the Castle Hill at Buda. Archaeological excavations have been carried out in Buda (between the Royal Palace and the Fehérvári Gate) between 1994 and 2003. The goal of these excavations was to launch an urban planning and space reconstruction project for a medieval district in the foreground of the former Royal Palace. The remains of a medieval foundry, that is, a moulding workshop were unearthed on some plots (6 and 8 Szent György Street) during these works. We have excavated the fragments of two brick-built furnaces and four moulding pits close to the medieval city wall. These pits were full with the waste of previous casts: moulded bricks, alloy and bronze pieces (flows and drops) of the casts and clay fragments from the mould. The size of the furnaces and the shape of the pits dug next to them all referred to the production of huge and heavy bronze objects. Therefore, we can identify these remains as the royal cannon foundry established by Jacobus Maryanwerder de Pruscia. This workshop was known from some written sources of the 15th and 16th centuries.

\section{Structure}

The goal of this dissertation is to reconstruct and present the cannon foundry working in Buda along the 15th and 16th centuries. It is based on the excavated archaeological material and the written sources relevant to history and technology.

The first part of the dissertation deals with the written military, economic and topographical history evidence of this workshop. This is followed by a comprehensive analysis of the sources relating to the casting history of the 15th and 16th centuries. This helps to demonstrate the contemporaneous procedure of cannon production. In the dissertation I presented a theoretical model of a cannon foundry as based on the written evidence.

In the next part, I compared the archaeological material of the excavated site with this theoretical model. The small finds were also analysed with scientific methods. This helped to understand excavated features and small finds and supported a theoretical structural reconstruction of the site and of the moulds. 
Finally, the internal structural context of the archaeological site made it possible to deter mine periods and internal relations of the site and the workshop areas inside of it.

\section{Written sources concerning the foundry at Buda}

The amount of the available written evidence is surprisingly large if compared to the general survival of the archival sources from the 15th century. There are charters from the Batthyányi archive (concerning the possession of Rohonc), well elaborated sources for house owners in the Szent György Street (the medieval Szent Zsigmond Street) in the city of Buda and royal reckoning books from the 1494 and 1495. This later describes the royal military campaign of Wladislas II against Lawrence of Ujlak, in which campaign the cannon foundry of Buda and its master played a crucial role.

The workshop leader of the cannon foundry, Jacobus Marijwerder (Maryanwerder, Morganwerder) de Pruscia, originates very likely from Marienberg, the Prussian settlement south of Malbork (today Kwidzyn in Poland). He most probably met and joined King Matthias during his Austrian campaign. His various services and support of the king were honoured by a donation in 1478: the villages of Hodász, Csajta, Perenye, Czag, Velem and Gwor, and the castle and town of Rohonc. Although there is no evidence for that, it is very likely that this royal master had soon moved to Buda, in the neighbourhood of the Royal Palace. The house of „facobi Bombardiste familiarum regie maiestatis” is first mentioned in a charter from 1489. It was located in the Saint Sigismund Street (Szent Zsigmond Street) leading to the castle, next to the house of the royal barber, Stephen of Raguza. "Facobus de Rohoncz pixidarius Regius" sold his newly acquired possession of Rohonc in several pieces between May 1490 and January 1491. His successor and official heir, Martinus de Pruscia „Bombardius regie maiestatis" is mentioned around 1505 . He is also mentioned in 1515 as a neighbour, and in 1518 as someone who sold his house a few years before for 1200 Forints to Emerich Perényi and his sons, the former southern neighbours of the plot.

\section{The royal reckoning books of 1494/1495}

The archive of the royal accounts is an important evidence for the investigation of the commerce and state budget in the era of the Jagiellonian dynasty. Some data in it also refer to the military campaign of the king against Lawrence of Ujlak. This information helps clarifying the role of Master Jacob and the royal artillery in this campaign. Although the wellspread data that all the royal cannons of the military enterprise had been casted by Jacob is not fully supported by evidence, this source is very informative concerning the artillery preparations at the late 15th century, the industrial achievement of the cooperation of several craftsmen and the role of the royal cannon master and artillery in general. The majority of the data in these books refer to supplementing munitions, producing gunpowder and moving cannons; only the casting of two cannons is fully evidenced.

\section{The topography of the cannon foundry in Buda}

The dissertation also considers topographic aspects in addition to the technological ones. The identification of this very special industrial area also helps localising the plots of the medieval „platea Sancti Sigismundi”, the later Szent György Street. There is a special investigation 
in the dissertation dedicated to the internal and external relationships of the foundry: the area of the workshop, its relation to the Royal Palace and fitting to the urban structure of late medieval and early modern Buda.

\section{Moulding and casting bronze cannons at about 1500}

The end of the 15th century is not simply the age of a military revolution, the general spread of the usage of artillery and firearms, but also the time of the establishment of the modern idea and literature of mining, geology and metallurgy. Incidentally, as referred to by the excavated remains of the furnace, the time of existence of the Buda cannon foundry and a shift in the Bronze casting technology coincide. A new type of cannon furnace appears: the so-called flame furnace.

While the casting technology had slightly changed thanks to the quick spread of the flame furnace, the mould-making technology had remained basically the same.

We can include a new source of evidence, because after this time the industrial technology of cannon casting procedure remained more or less the same for approximately 300 years. Analysing the relevant data of the 17 th and 18th centuries, we can also use the results for investigating the late medieval casting and mould-making technologies.

\section{The archaeological material of the workshop at Buda}

The dissertation investigates the features and small finds of the excavated foundry in the following structure:

- Identification of the material of the cannon foundry.

- Reconstruction of the historical industrial surroundings on the basis of comparing the excavation material and the sources of the history of technology.

- Moulds and casts as reconstructed from the finds.

- Relative chronology of the workshop.

\section{Results}

The given strict technology - as referred to by the sources - and the facilities connected to this technological process create a direct logical line, in which the missing elements can be inferred. Therefore, the fragments of the furnaces and pits are structural and technological elements, which refer to the whole procedure. Consequently, we can create models for the former medieval workshop also considering the local specialities.

Based on all the above evidence, we could reconstruct five workshop districts on the two excavated plots of the Szent György Street. We can also determine the size, weight and shape of the objects. Perhaps the most interesting is the identification and theoretical reconstruction of the cannon called ,...tormenta inusitate magnitudinis...” by Bonfini. We can presumably identify the mould remains of a cannon with extraordinary dimensions $(5705 \mathrm{~kg}$, at least $4,5 \mathrm{~m}$ long, $40 \mathrm{~cm}$ diameter) as the huge cannon which had been installed by Master Jacob on the field during the campaign against Újlaki. 
Although the evidence is not sufficient to create a solid typology for the firearms of the era, it is enough to set up a very likely hypothesis. At about 1500 the cannon workshop in Buda produced siege guns with one bigger and two smaller calibres, howitzers and a bell of more than $300 \mathrm{~kg}$ (with 100-120 cm lower diameter and 110-130 cm height).

\section{Summary}

Although the relative chronology and periods of the workshop could not be fully clarified, thanks to the written sources, the excavated material and the workshop districts could be very well located both in time and space.

According to the small finds, the stratigraphic observations and the numerous separated casting pits and furnaces, we have excavated the remains of several, non-contemporaneous casting procedures of cannons and bells. Only their succession in time, i.e. their relative chronological relationship remains unclear.

Because of the cannons, we can connect these casts to military actions and to the person of the king. In the case of the bells the customer was not necessarily the king and the production of smaller series is also probable.

Despite of the close neighbourhood of the Royal Palace, this foundry was not a royal military factory, but a privately owned manufacture, a cannon foundry, which also satisfied royal orders.

The manufacture run by first by Jacob and later by Martin is still interesting. Its speciality is its permanency; because of the typical mobility of the cannon foundry masters it is rather unique - although not exceptional - to settle in a city and create master dynasties for a longer time.

We know for sure that Martin and his wife, Margaret, sold their house in Buda in the 1510s. Martin could settle and get further orders elsewhere, but these are not known from the sources. The cannon foundry in the medieval Szent Zsigmond Street was established in the 1480s and was surely given up in 1518 the latest. The workshop is known to exist for approximately 30 years, but is without known predecessors and/or followers.

\section{References}

BÁN, A. 2011: A bronzágyúk öntéstechnikája a középkor és az újkor fordulóján. In: SzABó, S. (ed.): Örökös háború két világ határán - katonák, fegyverek és hadviselés a török elleni küzdelemben: Hadtörténeti konferencia a kenyérmezei csata 510. évfordulóján. Nyírbátor, 2009. október 13. Nyírbátor, 77-91.

BeléNyesy, K. 2009: Ami a tűzben fogant. Kísérlet a XV-XVI. század fordulóján működő budai ágyúöntő műhely rekonstrukciójára. In: ANDERs, A. - SzABó, M. - RACzky, P. (eds.): Régészeti dimenziók. Tanulmányok az ELTE BTK Régészettudományi Intézetének tudományos mühelyéből. Budapest, 139-151.

BELÉNYESY, K. 2008: A 15-16. század fordulóján Budán működött királyi ágyúöntő műhely régészeti hagyatéka. In: Hunyadi Mátyás, a király. Hagyomány és megújulás a királyi udvarban 14581490. Kiállítási katalógus. Budapest, 348-350. 
Biringuccio, V.: La Pyrotechnie, ou art du feu, contenant dix livres... Composée par le Seigneur Vanoccio Biringuccio Siennois. Et traduite d'Italien en François, par feu maistre Jaques Vincent. Édition: A Paris, Chez Claude Fremy, 1572 (Les Bibliothèques Virtuelles Humanistes: www.bvh.univ-tours.fr)

Dомокоs, Gy. 1997: A kassai királyi hadszertár fegyverzete és felszerelése a XVI-XVII. században az inventáriumok tükrében. Hadtörténelmi Közlemények 110.4, 667-747.

Dомокоs, Gy. 2004: Inventáriumok a Királyi Magyarországon és az Erdélyi Fejedelemségben a 16-17. században: váraink fegyverzete és hadifelszerelése. Unpublished PhD-thesis. Budapest.

Engels, G. - Wübbenhorst, H. 1994: 5000 fahre Giessen von Metall. Fakten, Daten, Bilder zur Entwicklung der Giessereitechnik. Düsseldorf.

KuBINyi, A. 2007: Hadszervezet a késő középkori Magyarországon. In: KuBINYi, A.: Nándorfehérvártól Mohácsig. A Mátyás-és a fagelló-kor hadtörténete. Budapest, 199-215.

MülLER, H. 1968: Deutsche Bronzegeschützrohre. 1400-1750. Berlin.

RidelLA, R.G. 2014: L'evoluzione strutturale nelle artiglierie di bronzo in Italia tra XV e XVII secolo. In: Beltrame, C. - Morin, M. (eds.): I Cannoni di Venezia Artiglierie della Serenissima da fortezze e relitti. Firenze, 13-29.

Ringer, I. 2011: I. Rákóczi György ágyúöntő mühelye. A kora újkori ágyúöntés technológiája. Sárospatak.

Schmidtchen, V. 1977: Bombarden, Befestigungen, Büchsenmeister. Von den ersten Mauerbrechern des Spätmittelalters zur Belagerungsartillerie der Reneissance. Düsseldorf.

VÉGH, A. 2003: Középkori városnegyed a királyi palota előterében (A budavári Szent György tér és környezetének története a középkorban). Tanulmányok Budapest múltjából 31, 7-43.

VÉGH, A. 2003: A Szent György utca 4-10. számú telkek régészeti ásatása (előzetes jelentés). Tanulmányok Budapest múltjából 31, 167-191.

VÉGH, A. 2006: Buda város középkori helyrajza I. Monumenta Historica Budapestinensia XV. Budapest.

VÉGH, A. 2008: Buda város középkori helyrajza II. Monumenta Historica Budapestinensia XVI. Budapest. 


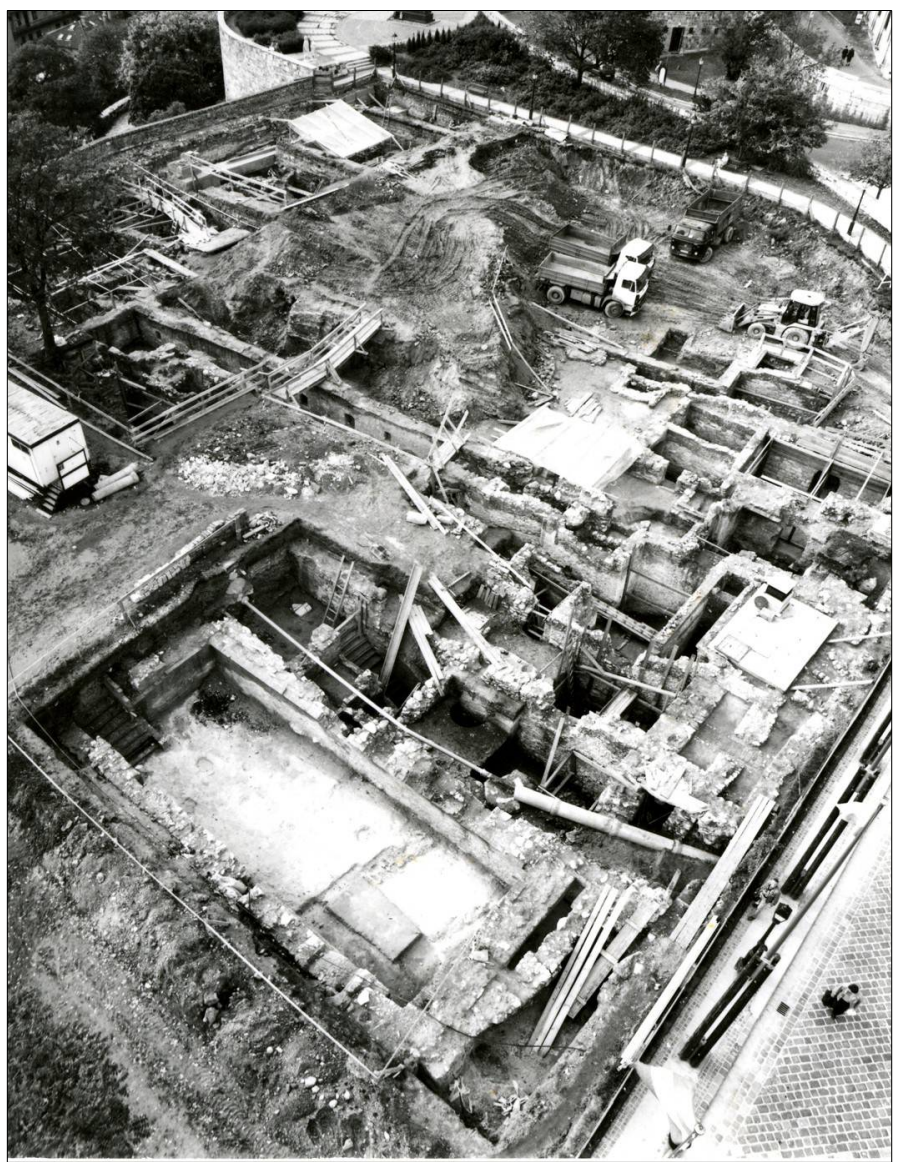

Fig. 1. Aerial photo of the excavation at Szent György Street in 1999.

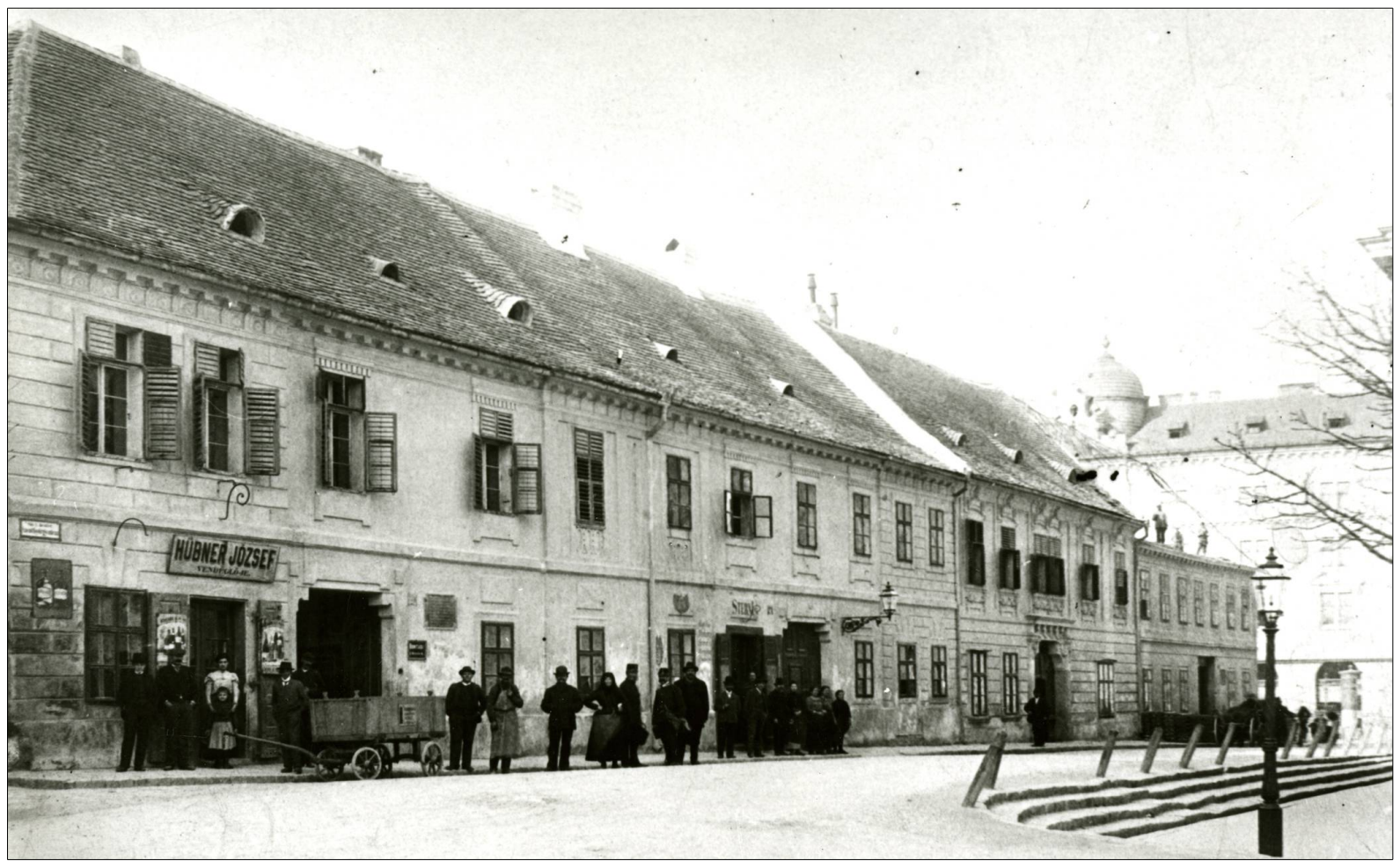

Fig. 2. Photo of Szent György Street around 1890. 


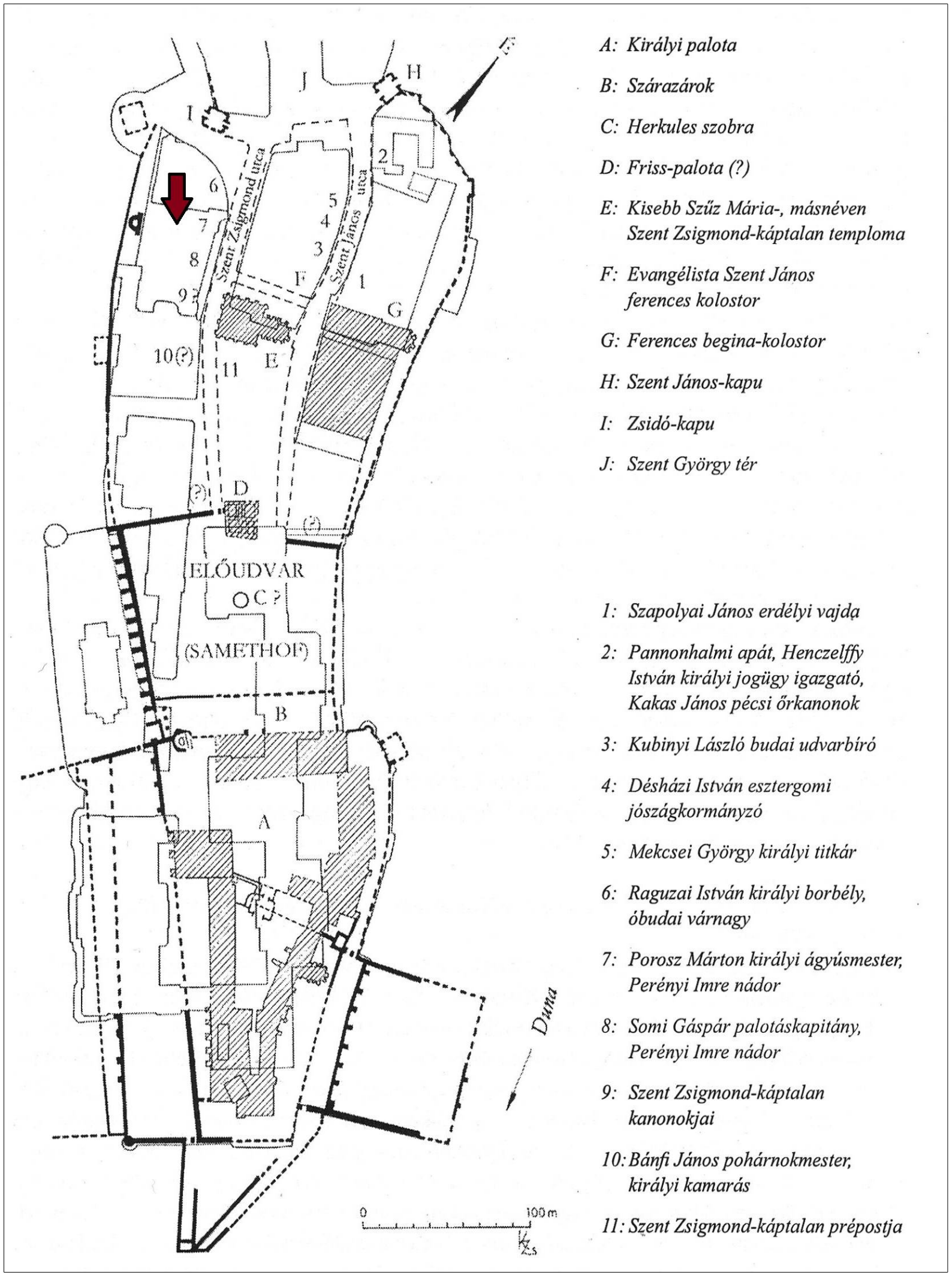

Fig. 3. Map of the Late Medieval house structures of Szent György Street (Medieval Szent Zsigmond Street) with the indication of the cannon foundry (drawing by Zs. Kuczogi). 

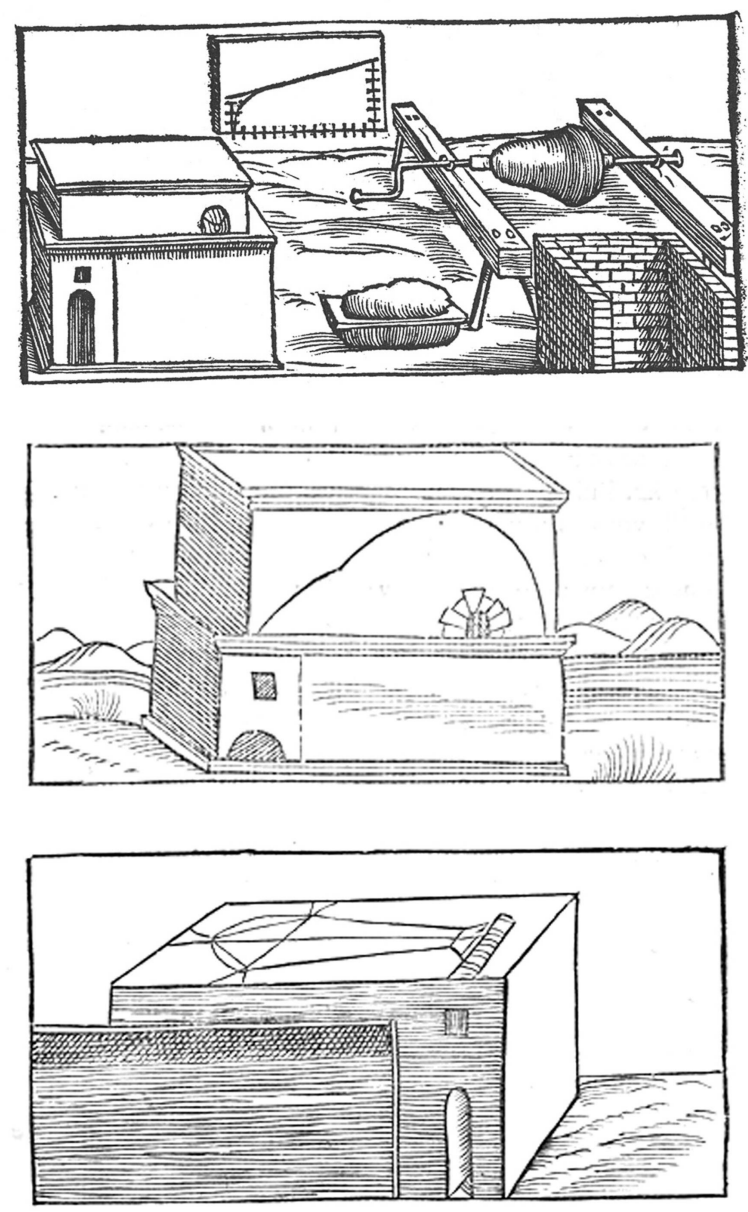

Fig. 4. Illustrations of flame furnaces from the book of Vannoccio Biringucco.

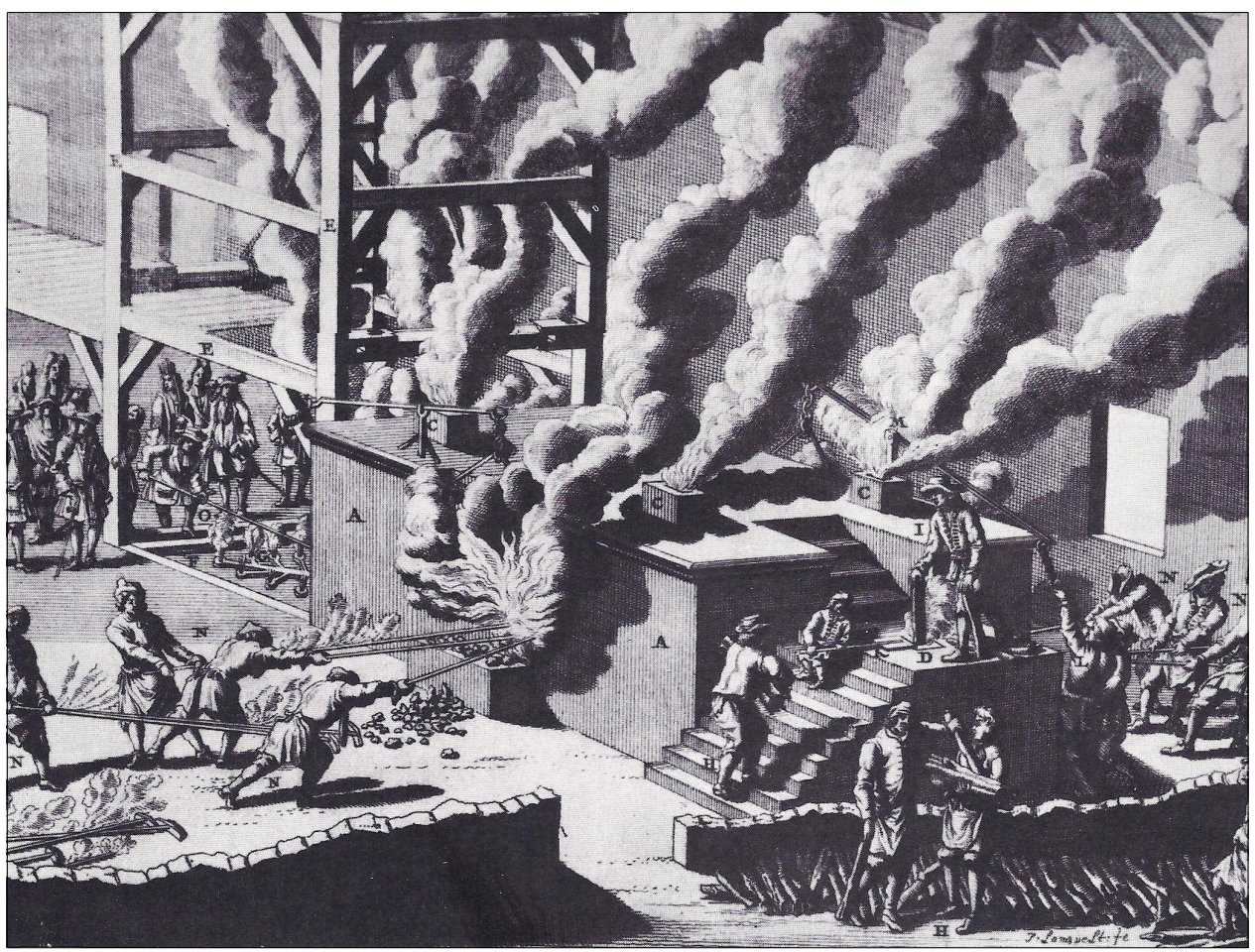

Fig. 5. Illustration of an 18th century cannon foundry. 


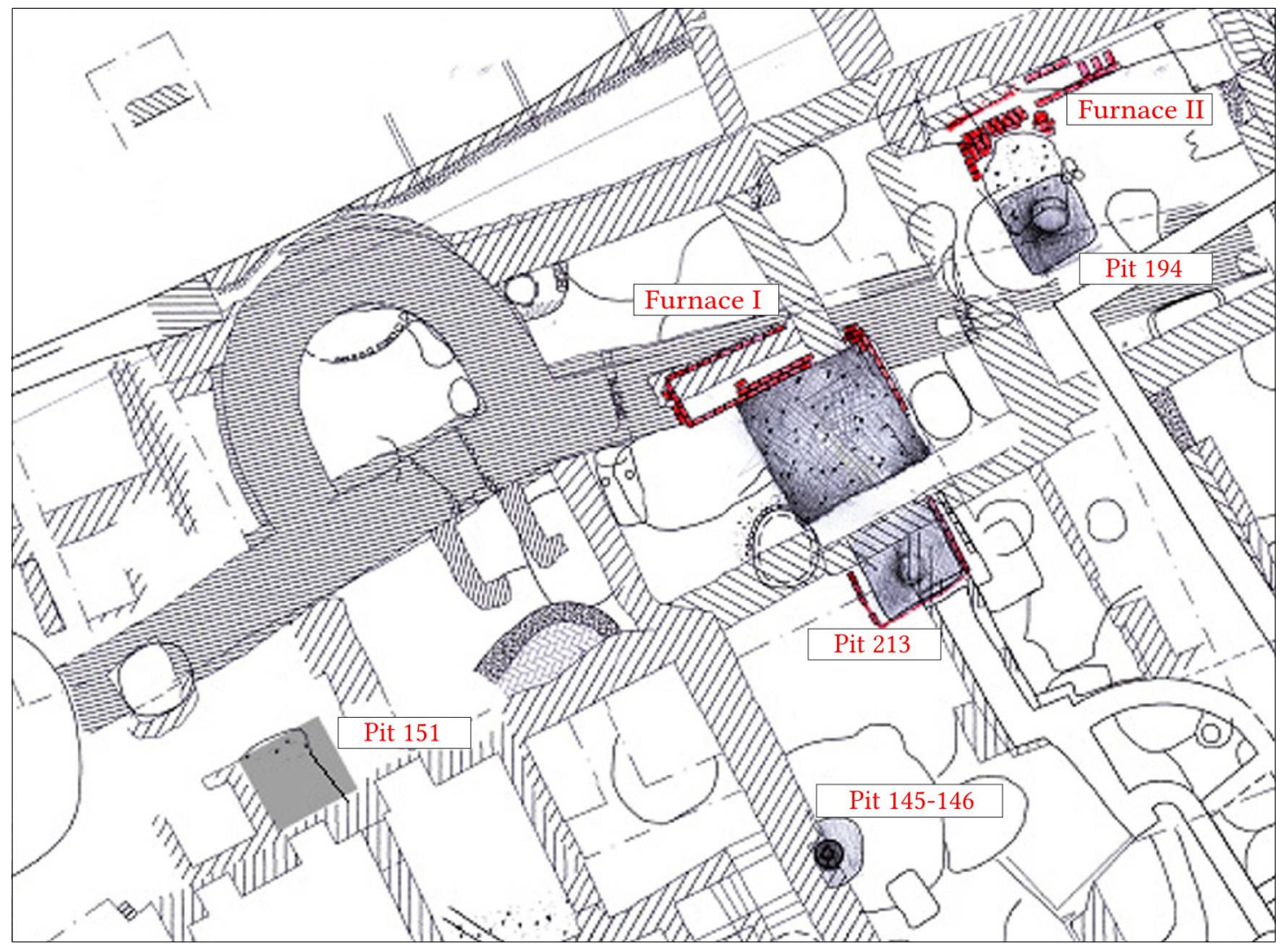

Fig. 6. Remains of the gun foundry in building plots 6 and 8 Szent György Street, close to the city walls.

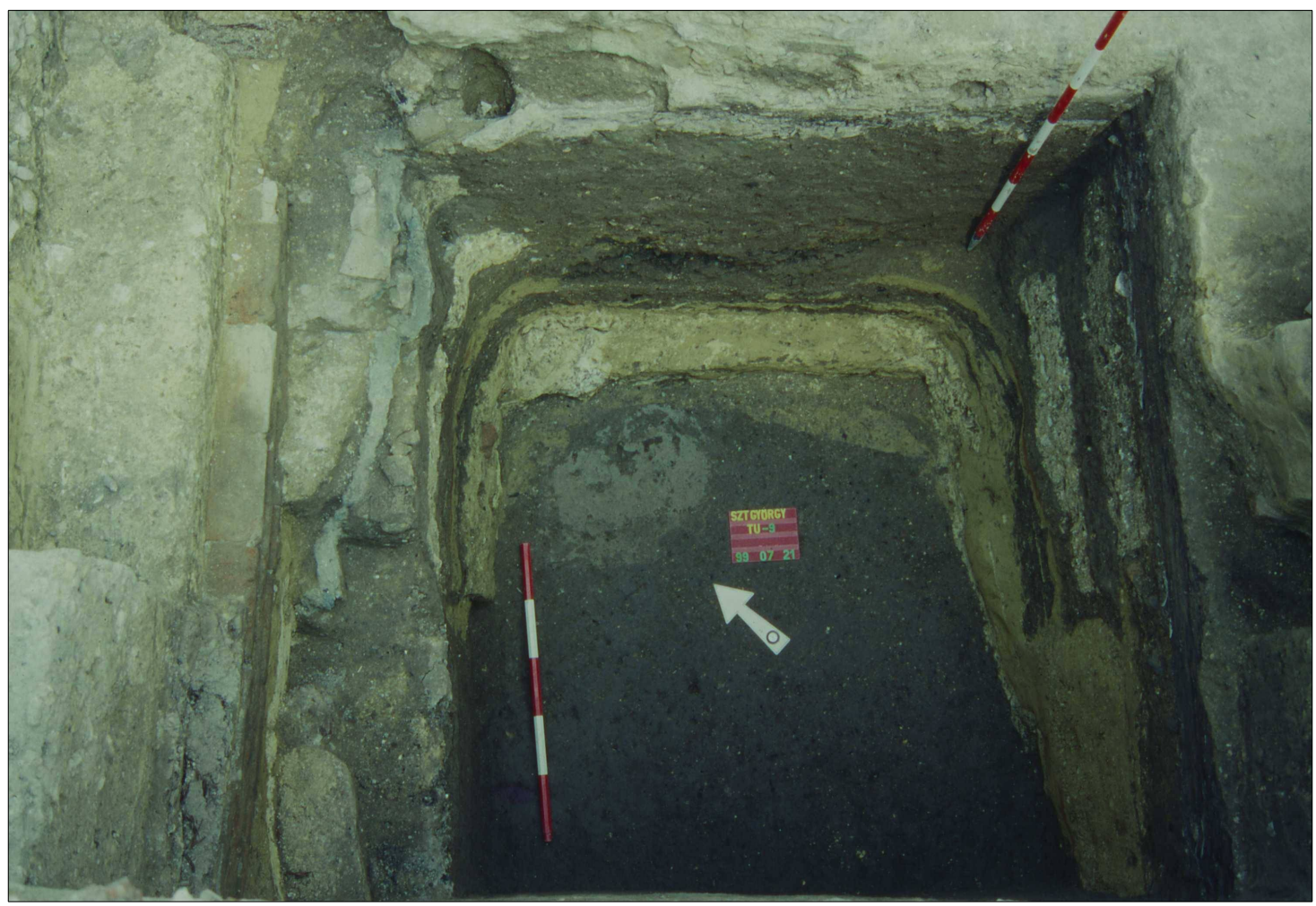

Fig. 7. Casting pit nr. 213 under excavation. 


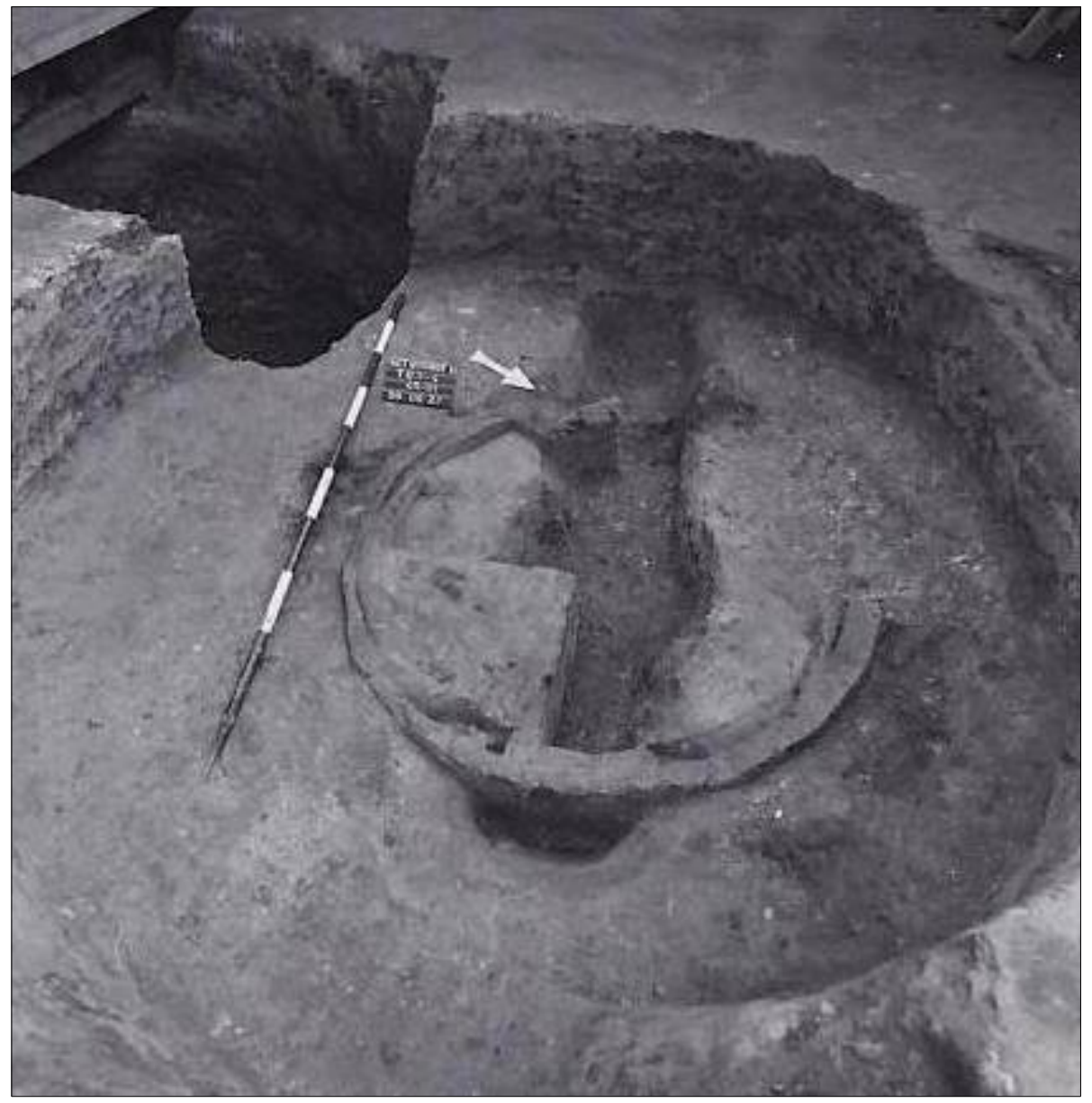

Fig. 8. Excavation photo of a bell casting pit from the parcel of the 15 th-16th century gun foundry.

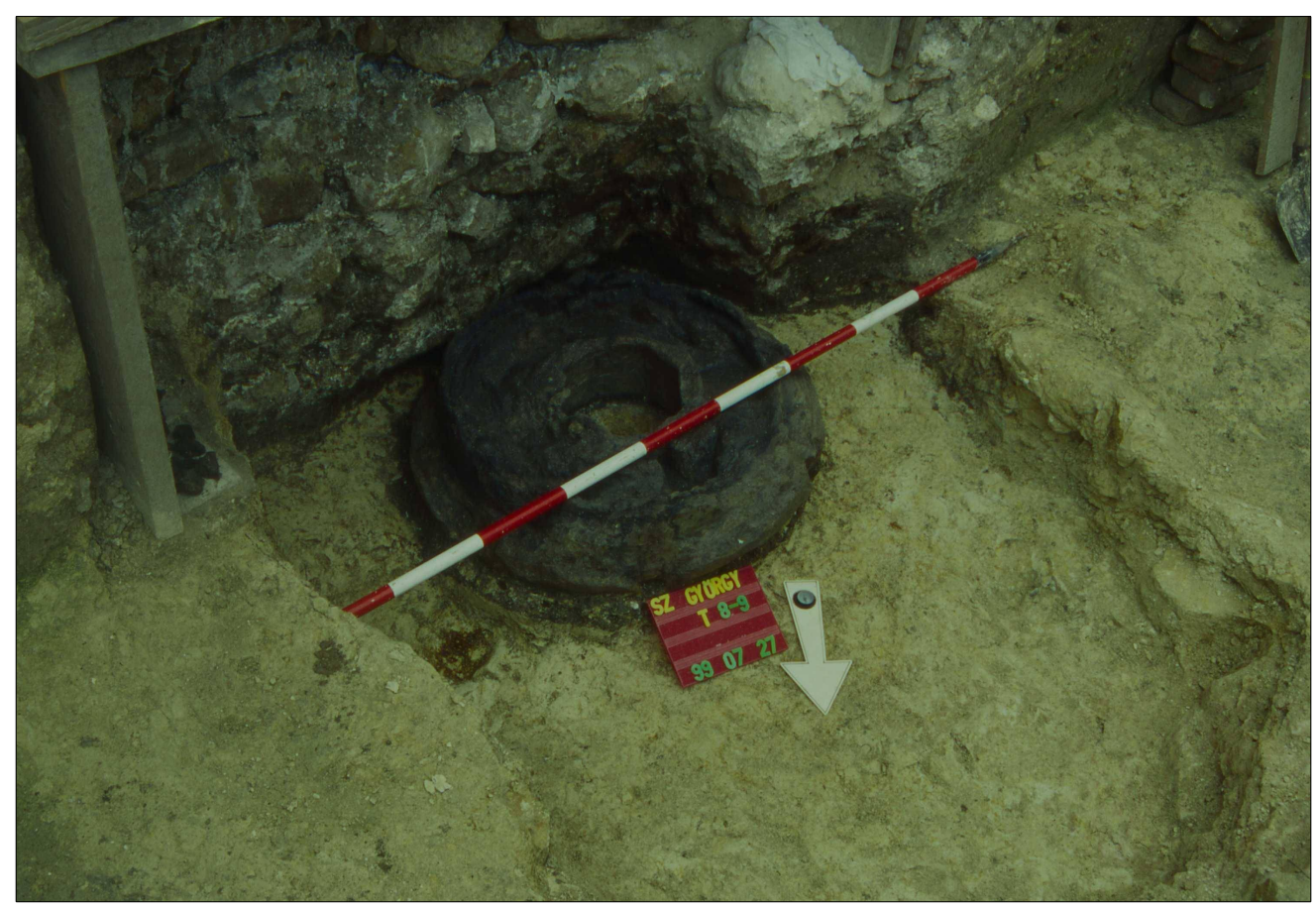

Fig. 9. Fragments of a casting form from casting pit nr. 145. 


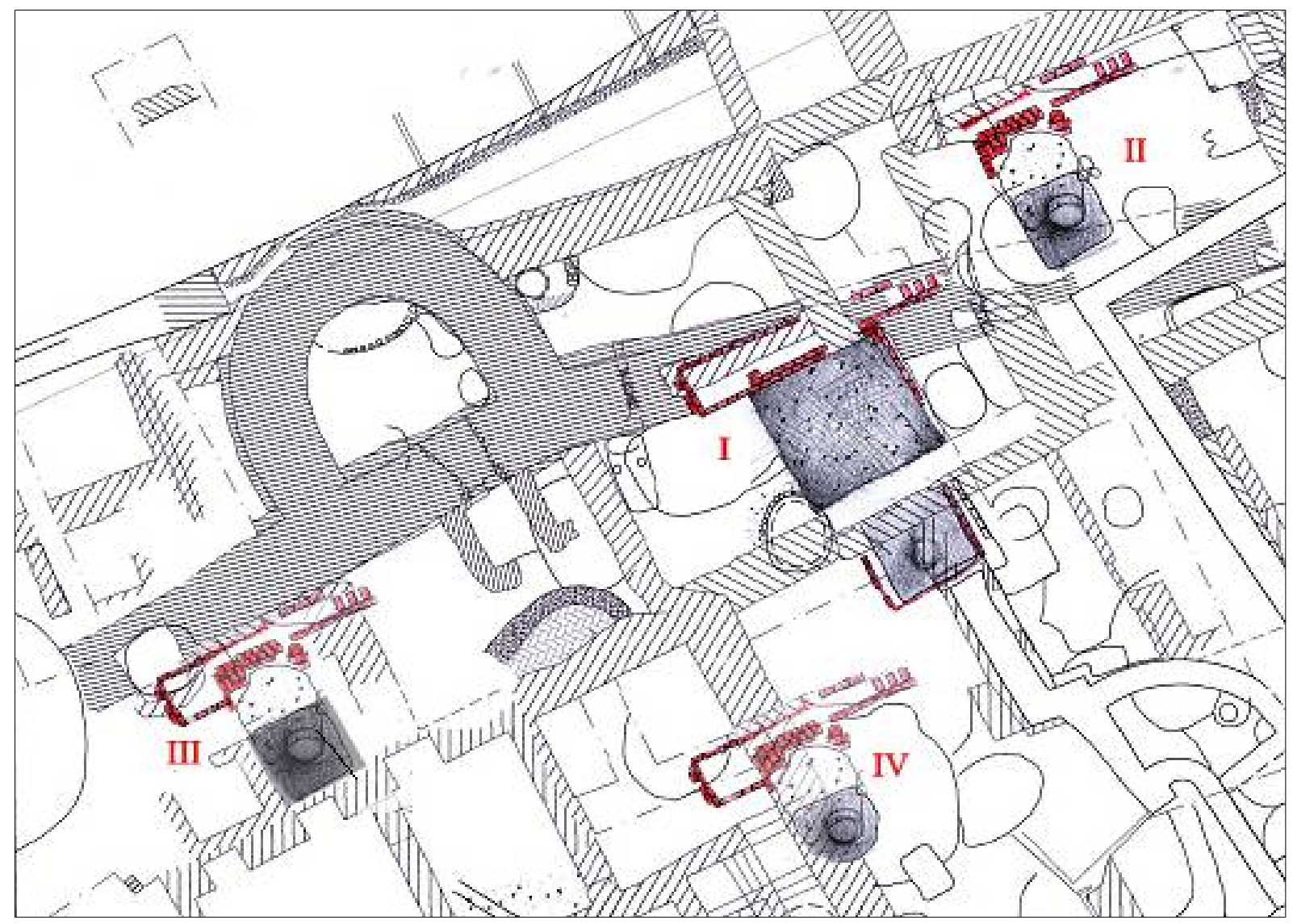

Fig. 10. Reconstructed drawing of the working areas of the foundry based on the small finds and remains of the 15th-16th century casting furnaces.

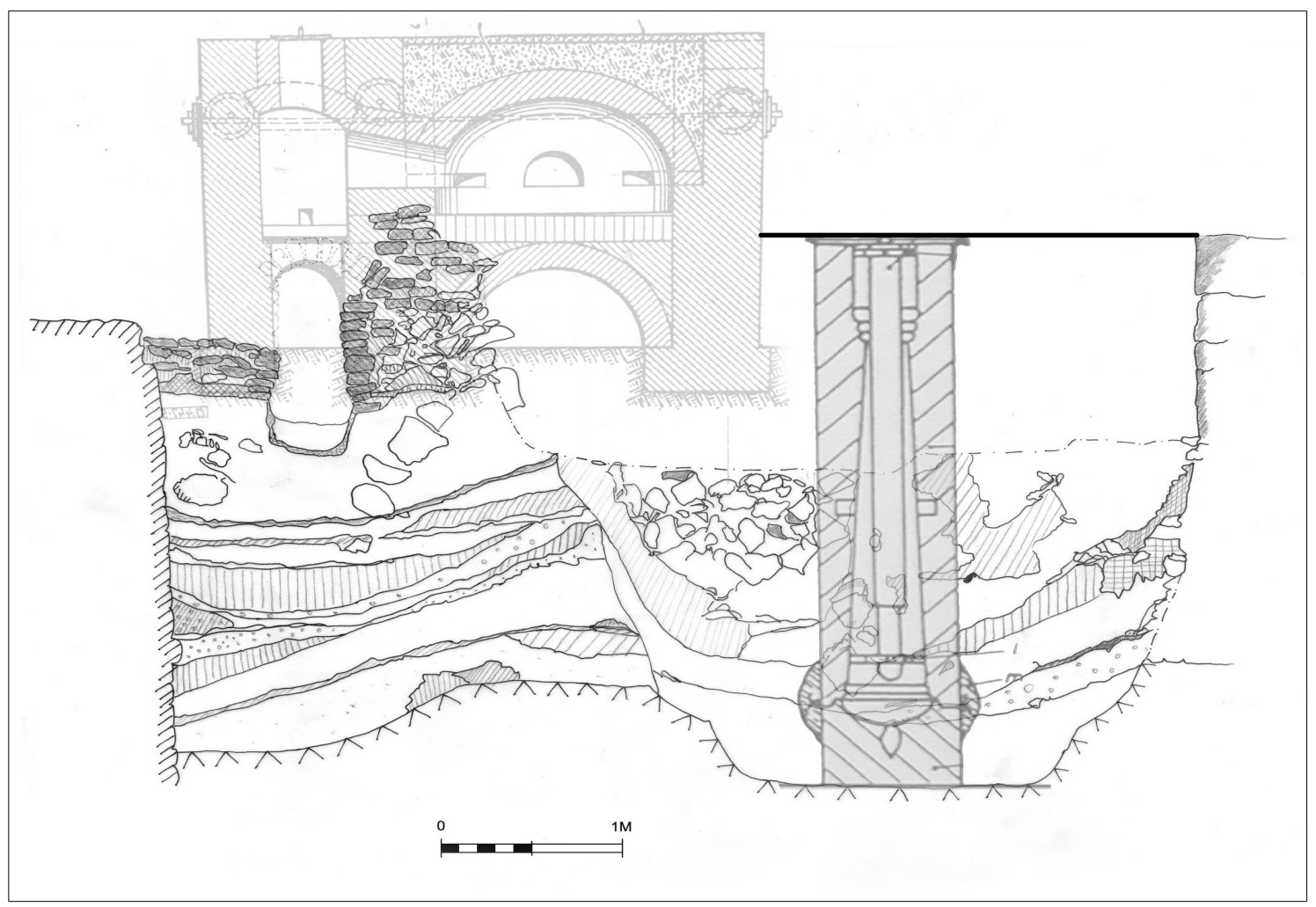

Fig. 11. Reconstructed flame furnace nr. II with the illustration of the casting form of a cannon. 


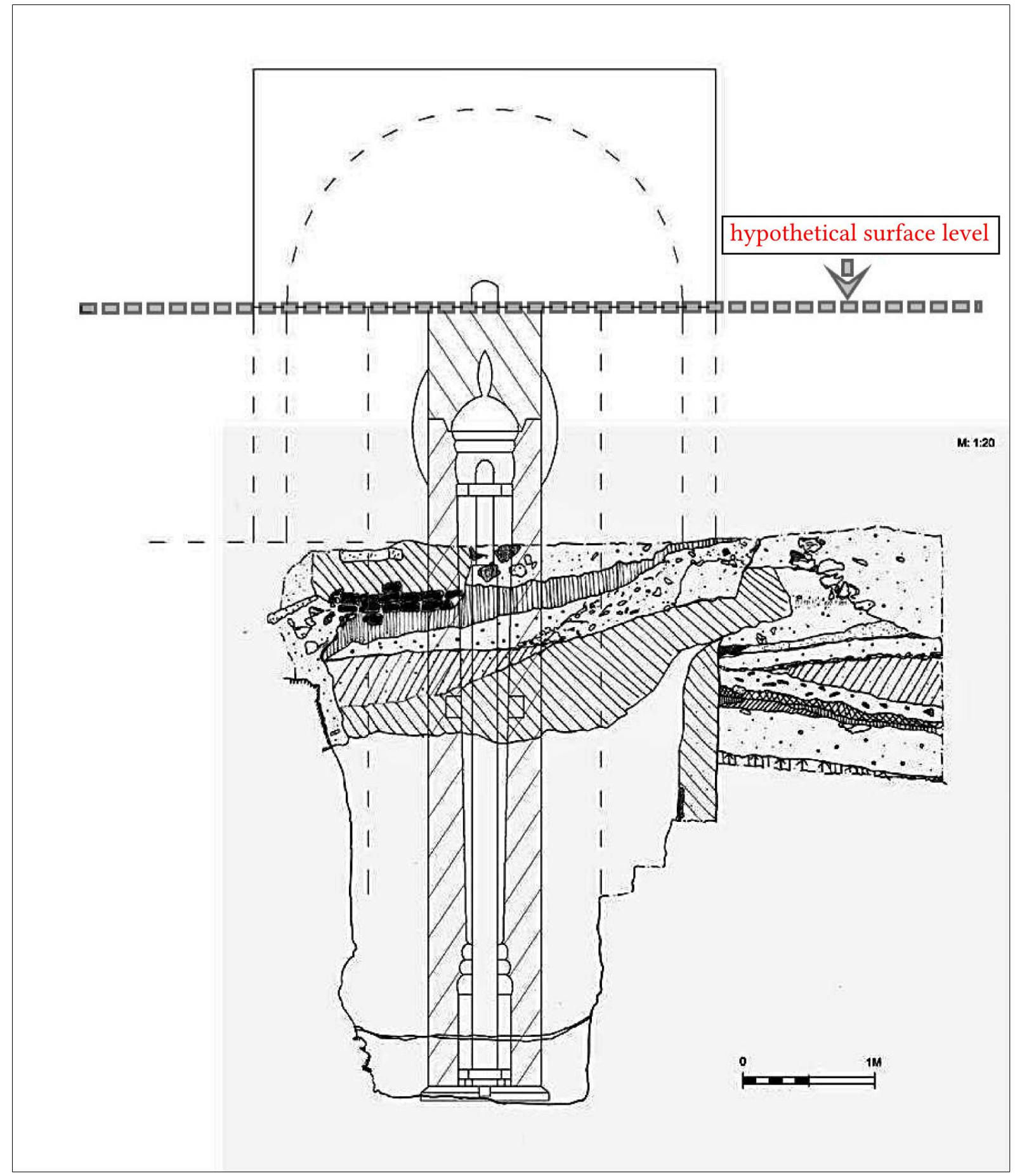

Fig. 12. Reconstructed flame furnace nr. I. with the hypothetical surface level of the cannon foundry and the working areas. 